\title{
COMMENTS
}

\section{Parts and Service Included: An Information-Centered Approach to Kodak and the Problem of Aftermarket Monopolies}

\author{
Salil Kumart
}

\begin{abstract}
Durable goods ranging from farm machinery to computer hardware invariably require service, supplies, or replacement parts after their initial sale. The influence of original equipment makers ("OEMs") in the secondary market (or "aftermarket") for such complementary goods has attracted recent legal attention. In the classical economic world of perfect, costless information, OEMs could not wield monopoly power ${ }^{1}$ in these aftermarkets, because consumers would factor the necessary complements of a product into its price. As a result, an OEM that charged higher prices in the aftermarket would soon lose sales in the market for original equipment. Accordingly, until the Ninth Circuit's ruling in Image Technical Service, Inc. $v$ Eastman Kodak Co., ${ }^{2}$ the circuit courts had adopted as law the economic argument that an
\end{abstract}

$\dagger$ A.B. 1991, Harvard University; J.D. 1995, The University of Chicago.

1 Antitrust law has traditionally focused on the problem of monopolies. See Herbert Hovenkamp, Federal Antitrust Policy: The Law of Competition and Its Practice $\$ 1.3$ at 19 (West, 1994). Economic theory predicts that monopoly firms can charge consumers higher prices than firms in competitive markets. Id $\S 1.2$ at 12 . The Supreme Court has defined this "monopoly power" or, as it is referred to more generally, "market power," as "[ $t$ ]he power [of a seller] to set higher than competitive prices." Matsushita Electric Industrial Co. $v$ Zenith Radio Corp, 475 US 574, 590 (1986). See also Eastman Kodak Co. v Image Technical Services, Inc., 112 S Ct 2072, 2080 (1992), quoting Jefferson Parish Hospital District No. $2 v$ Hyde, 466 US 2, 14 (1984) ("Market power is the power 'to force a purchaser to do something that he would not do in a competitive market.").

${ }^{2} 903$ F2d 612 (9th Cir 1990), aff'd 112 S Ct 2072 (1992). 
OEM that sold in a competitive primary market could not be a monopolist in its product's aftermarket. ${ }^{3}$

The Supreme Court's decision in Eastman Kodak Co. $v$ Image Technical Services, Inc. ${ }^{4}$ called previous use of economic theory into question. ${ }^{5}$ The Court noted that in the real world, information is costly and difficult to obtain, so consumers might not know the life-cycle cost of operating and maintaining durable equipment. ${ }^{6}$ Accordingly, the Court posited that OEMs could charge consumers monopolistic prices in aftermarkets for services and parts without affecting competitive primary markets. ${ }^{7}$ Simply put, if consumers purchased the original equipment without good information on aftermarket costs, and if switching to other products were expensive, then OEMs could charge excessive prices for aftermarket goods. ${ }^{8}$

Although the Kodak Court expressed a well-founded concern about the effects of information costs on the "commercial realities" faced by consumers, ${ }^{9}$ the Court left little guidance as to how to interpret such market imperfections, leaving courts and private parties confused as to what conduct is illegal. Moreover, the Kodak decision called for a more fact-intensive trial inquiry, which might impede summary judgment ${ }^{10}$ and contradict the

${ }^{3}$ See Kodak, $112 \mathrm{~S} \mathrm{Ct}$ at 2100 (Scalia dissenting), citing Virtual Maintenance, Inc. $v$ Prime Computer, Inc., 957 F2d 1318, 1328 (6th Cir 1992), vacated for further consideration, 113 S Ct 314 (1992); Grappone, Inc. v Subaru of New England, Inc., 858 F2d 792, 798 (1st Cir 1988); A.I. Root Co. v Computer/Dynamics, Inc., 806 F2d 673, 675-77 \& n 3 (6th Cir 1986); General Business Systems v North American Philips Corp, 699 F2d 965, 977 (9th Cir 1983). See also Kodak, 903 F2d at 621-23 (9th Cir 1990) (Wallace dissenting) (questioning majority's attempt to distinguish Kodak from General Business Systems).

4112 S Ct 2072 (1992).

5 See Michael S. Jacobs, Market Power through Imperfect Information: The Staggering Implications of Eastman Kodak Co. v. Image Technical Services and a Modest Proposal for Limiting Them, 52 Md L Rev 336, 358-60 (1993) ("[A]long with FTC v. Ticor Insurance $\mathrm{Co}$. [a 1992 case reexamining the state-action immunity defense], Kodak apparently reverses the general direction of antitrust jurisprudence set by the Court over the past fifteen years. During that time, ... the Court consistently contracted the scope of judicial involvement in antitrust enforcement, often relying on economic theory to resolve disputed issues at the summary judgment stage.").

6 Kodak, 112 S Ct at 2086.

7 Id at 2086-88.

${ }^{8}$ Id.

9 Id.

10 See Michael S. Jacobs, The New Sophistication in Antitrust, 79 Minn L Rev 1, 24 (1994); William W. Schwarzer and Alan Hirsch, Summary Judgment After Eastman Kodak, 45 Hastings I J 1, 8-10 (1993) (recognizing that Kodak might effectively raise the standard for summary judgment in antitrust cases). Making summary judgment more difficult to obtain is especially troublesome because antitrust cases can consume tremendous resources. See, for example, Allen-Myland, Inc. v IBM Corp, 33 F3d 194, 198 n 2 (3d Cir 1994), cert denied, 115 S Ct 684 (1994) (" $[F]$ inding facts or reviewing those findings for 
Court's emphasis on administrative efficiency in antitrust law. ${ }^{11}$

In response to these difficulties, this Comment advocates a rule that exempts OEMs from antitrust liability in aftermarkets when, at the time of purchase, OEMs offer consumers fairly priced contracts to supply aftermarket goods for the reasonable lifetime of the durable equipment. This rule borrows from the logic behind warranties: ${ }^{12}$ commentators on consumer product warranties argue that consumers can and will use information contained in the price and terms of a warranty to assess product risks that they will face after purchase. ${ }^{13}$ Much like product warranties, the prices and terms of aftermarket supply contracts would enable consumers to estimate the life-cycle costs of original equipment. A rule exempting from antitrust liability those OEMs that offer such contracts would conserve social resources by providing businesses with clearer guidance and by simplifying the questions for courts dealing with aftermarket monopolies. Thus, this rule not only accords with Kodak's text but also maintains proper concern for the effects of information costs. ${ }^{14}$

clear error is no easy task. The thirty-volume record on appeal contains 17,469 pages of court flings, trial and deposition transcripts, and exhibits. The district court, of course, was in an even more difficult position. Over 3.5 million pages of discovery documents were produced and 65 days of deposition testimony were taken.").

"See Jacobs, 79 Minn L Rev at 24. The Court has emphasized summary judgment as a device to achieve such efficiency. See, for example, FTC v Superior Court Trial Lawyers Ass'n, 493 US 411, 430 (1990) ("The administrative efficiency interests in antitrust regulation are unusually compelling.").

12 The primary economic argument that warranties are efficient is based on this transfer of information. See Note, Imperfect Information, the Pricing Mechanism, and Products Liability, 88 Colum L Rev 1057, 1063 (1988) ('[E]mbedded in the product's total price [including the warranty] are the manufacturer's best estimates of the probabilities of various product defects and the magnitude of the losses involved."). Note that a warranty is a type of contract. See George L. Priest, A Theory of the Consumer Product Warranty, 90 Yale L J 1297, 1297 (1981).

${ }^{13}$ See, for example, George A. Akerlof, The Market for "Lemons": Quality Uncertainty and the Market Mechanism, 84 Q J Econ 488, 499 (1970); A. Michael Spence, Market Signaling: Informational Transfer in Hiring and Related Screening Processes 88-90 (Harvard, 1974). See also W. Keith Bryant and Jennifer L. Gerner, The Price of $a$ Warranty: The Case for Refrigerators, $12 \mathrm{~J}$ Consumer Aff 30, 32 (Summer 1978); Jennifer L. Gerner and W. Keith Bryant, Appliance Warranties as a Market Signal? $15 \mathrm{~J}$ Consumer Aff 75, 77-86 (Summer 1981) (empirical work confirming some of the theorists' predictions); Priest, 90 Yale $\mathrm{L} J$ at 1303, 1306 (noting that the objective of the 1974 MagnusonMoss Warranty Act was to make warranties more efficient signals of quality to aid consumer choice).

14 See Gordon B. Spivack and Carolyn T. Ellis, Kodak: Enlightened Antitrust Analysis and Traditional Tying Law, 62 Antitrust L J 203, 206 (1993) (commending the Court's balanced decision to bring market imperfections such as information and switching costs into antitrust analysis without "a wholesale rejection of economic theory"); Comment, Rewriting the Law of Resale Price Maintenance: The Kodak Decision and Transaction Cost Economics, 143 U Pa L Rev 321, 360 (1994) (suggesting that Kodak's emphasis on market 


\section{KODAK AND ITS CURRENT INTERPRETATIONS}

Kodak must be considered against the backdrop of antitrust law, which has historically focused on prohibiting monopolies. ${ }^{15}$ Economic theory predicts that a monopolist will injure consumers by reducing supply, thereby raising prices. ${ }^{16}$ In a competitive market, if one firm raises its prices above the market price, other firms will undercut the firm and lure away consumers. ${ }^{17}$ But a monopolist, by definition, is the only firm in the market and so may, without fear of competition, raise prices to whatever level maximizes its profits. ${ }^{18}$

Courts have applied the Sherman Act ${ }^{19}$ by searching out harms to consumers associated with monopolies. Consequently, antitrust law has developed a body of concepts (and a vocabulary) to assess such harms. The Supreme Court has defined "market power," a prerequisite for most antitrust injuries, as " $t]$ he power [of a seller] to set higher than competitive prices." ${ }^{\text {"20 }}$ As a result, to win antitrust claims, plaintiffs must prove that a defendant firm possesses "market power."21 As a proxy for "market power," courts have used the more measurable "market share"-the percentage of sales in a relevant market made by the firm in question. The higher the market share, it is assumed, the more likely that market power exists. ${ }^{22}$ Of course, to determine market

imperfections will benefit antitrust analysis of resale price maintenance practices).

${ }_{15}$ A monopoly is defined as a market with one seller. Hovenkamp, Federal Antitrust Policy $\$ 1.2$ at 12 (cited in note 1). Section 2 of the Sherman Act calls for fines and/or imprisonment for every single person who monopolizes, or attempts to monopolize, interstate commerce. 15 USC \& 2 (1988 \& Supp 1990).

${ }_{16}$ Hovenkamp, Federal Antitrust Policy $\$ 1.2$ at 12 (cited in note 1). It has been argued that some monopolies benefit consumers by increasing overall efficiency and reducing costs. See Richard A. Posner and Frank H. Easterbrook, Antitrust: Cases, Economic Notes and Other Materials 394-95 (West, 2d ed 1981).

${ }_{17}$ Hovenkamp, Federal Antitrust Policy $\S 1.1$ at 8 (cited in note 1).

${ }^{18}$ Some economists also emphasize the importance of "barriers to entry." If competitors can quickly and cheaply enter the monopolized market, then the monopolist will hesitate to raise its prices above the competitive level. See, for example, R.E. Caves and M.E. Porter, Market Structure, Oligopoly, and Stability of Market Shares, $26 \mathrm{~J}$ Industrial Econ 289 (1978). See also Avinash Dixit, A Model of Duopoly Suggesting a Theory of Entry Barriers, 10 Bell J Econ 20 (1979) (suggesting a general theoretical approach for analyzing the decisions of potential entrants facing barriers). For a general discussion of entry barriers, see Posner and Easterbrook, Antitrust at 513.

1915 USC $\$ \S 1$ et seq (1988 \& Supp 1990).

${ }^{20}$ Matsushita Electric Industrial Co. $v$ Zenith Radio Corp, 475 US 574, 590 (1986). See also note 1 and accompanying text.

${ }_{21}$ Matsushita, 475 US at 590. See also Kodak, 112 S Ct at 2080-81.

${ }_{22}$ See Kodak, 112 S Ct at 2081; Jefferson Parish Hospital District No. 2 v Hyde, 466 US 2, 17 (1984). 
share, courts must engage in "market definition": they must decide what products and firms make up the "relevant market."23

Prior to the Ninth Circuit's Kodak decision, several circuits had accepted that, as a matter of law, an OEM that competed in a competitive primary market could not be a monopolist in its product's aftermarket, even if it sold $100 \%$ of its product's aftermarket needs. ${ }^{24}$ The Ninth Circuit, however, rejected this theory in the Kodak case, positing that "market imperfections can keep economic theories about how consumers will act from mirroring reality."25 Affirming this ruling, the Supreme Court opened up product aftermarkets to antitrust scrutiny, even when the original product market is competitive. ${ }^{26}$

\section{A. Kodak}

The Kodak opinion makes it easier for plaintiffs in an antitrust suit to oppose summary judgment motions that are grounded primarily in economic theory rather than fact ${ }^{27}$ and calls for courts to conduct evaluations of market imperfections made possible by information costs. ${ }^{28}$ In Kodak, defendant Eastman Kodak faced a competitive market in the primary market for photocopiers: $:^{29}$ enough companies manufactured copiers that no one company could charge supracompetitive prices and still maintain its market share.$^{30}$ Relying on existing case law, Kodak argued

23 See Herbert Hovenkamp, Economics and Federal Antitrust Law $\$ 3.2$ at 59 (West, 1985) (The inference is strong that a firm with a high share of a relevant market has market power. Markets do not define themselves, however.").

24 See, for example, Virtual Maintenance, Inc. v Prime Computer, Inc., 957 F2d 1318, 1328 (6th Cir), vacated for further consideration, $113 \mathrm{~S} \mathrm{Ct} 314$ (1992); Grappone, Inc. $v$ Subaru of New England, Inc., 858 F2d 792, 798 (1st Cir 1988).

25 Kodak, 903 F2d at 617.

${ }^{26}$ Kodak, 112 S Ct at 2087-88.

27 See Jacobs, 79 Minn L Rev at 26 (cited in note 10) (suggesting that Kodak makes it easier for plaintiffs to oppose summary judgment motions based primarily on economic theory). But see Schwarzer and Hirsch, 45 Hastings I J at 10 (cited in note 10) (arguing that because the Court in Kodak did not discuss certain previous summary judgment cases, lower courts should read Kodak not as raising new barriers to summary judgment, but as clarifying specific points in antitrust law). Note that Judge Schwarzer issued the district court decision in Kodak, which the Ninth Circuit overturned. Image Technical Services, Inc. v Eastman Kodak Co., 1989-1 Trade Cases (CCH) I1 68,402 (N D Cal 1988), rev'd, 903 F2d 621 (9th Cir 1990), aff'd, 112 S Ct 2072 (1992).

2s See Jacobs, $52 \mathrm{Md} \mathrm{L} \mathrm{Rev} \mathrm{at} 365$ (cited in note 5) ("[L]ower courts considering the rationale of Kodak, and not just its vocabulary, will likely feel bound, logically and equitably, to extend its application to almost every market and information gap.").

2o Kodak, 112 S Ct at 2081 n 10.

30 See Hovenkamp, Federal Antitrust Policy $\S 3.3$ at 93 (cited in note 1) (noting that Kodak had a 20-23 percent market share in photocopiers, which is below what courts 
that it could not charge monopolistic prices in the aftermarket for parts and supplies, since consumers would factor the higher aftermarket prices over the life of the photocopier into their purchasing decision. ${ }^{31}$ The Supreme Court rejected this argument and denied Kodak summary judgment. The Court concluded that "[t]he fact that the equipment market imposes a restraint on prices in the aftermarkets by no means disproves the existence of [market] power in those [after]markets. ${ }^{\prime 32}$ The Court noted that lack of information could prevent consumers from factoring the higher aftermarket prices into their original purchasing decisions. ${ }^{33}$ Purchasers who did not anticipate high-priced service and parts would have to pay such prices because their investment would prevent easy switching-giving Kodak market pow$\mathrm{er}^{34}$

In response Kodak argued that market imperfections, though possible, did not in fact injure consumers in the market for photocopiers. According to Kodak, many of its customers were "sophisticated purchasers" who could undertake comparative studies and demand competitive life-cycle prices. ${ }^{35}$ Sophisticated consumers, Kodak argued, would not buy original equipment at supracompetitive prices. ${ }^{36}$ Further, Kodak argued that the behavior of sophisticated consumers would bring unduly high aftermarket costs to the attention of unsophisticated consumers. ${ }^{37}$

Although the Court accepted the idea that well-informed consumers did not need antitrust protection from informationdriven market imperfections, the Court concluded that Kodak might be able to overcharge "unsophisticated" consumers, ${ }^{38}$ thereby still reaping monopoly profits. ${ }^{39}$ Alternatively, the Court

usually require "to support market power claims of any sort, including tying claims"). See also id, citing, for example, Jefferson Parish Hospital District No. 2 v Hyde, 466 US 2 (1984) (a tying case where 30 percent was ruled insufficient).

31 112 S Ct at 2081-82.

32 Id at 2084.

${ }^{33}$ Id at 2086-87.

34 Id at 2087.

${ }^{35}$ Id.

${ }^{36}$ Id.

37 Id.

${ }^{38}$ Note that antitrust law makes this distinction in other areas, including the determination of which mergers to bar as anticompetitive. See Hovenkamp, Federal Antitrust Policy $\S 12.5$ at 479 (cited in note 1) ("Courts have often cited the presence of powerful or sophisticated buyers or suppliers as militating against the likelihood of any exercise of market power by a merging firm.”). See also FTC v Elders Grain, Inc., 868 F2d 901, 905 (7th Cir 1989) (" $\mathrm{A}$ concentrated and knowledgeable buying side makes collusion by sellers more difficult.").

${ }^{39} 112 \mathrm{~S} \mathrm{Ct}$ at 2086-87. Price discrimination occurs when a firm makes sales at more 
suggested that Kodak might forgo sophisticated buyers to soak the unsophisticated..$^{40}$

In effect, the Supreme Court's ruling opened up a new line of argument in the litigation of OEM aftermarket monopolies. ${ }^{41}$ The Court pointed out that an OEM in a competitive primary market could still possess market power in the aftermarket, so long as certain information-driven market imperfections were prominent enough. ${ }^{2}$ Unfortunately, the Court gave little guidance to lower courts on how to apply its discussion of market imperfections.

\section{B. Lower Courts}

Lower courts have adopted at least two approaches since Kodak. Some courts have emphasized that when a defendant offers "factual data," and not just pure economic theory concerning the relationship between the primary and secondary markets, Kodak is "inapposite" and summary judgment may be granted. ${ }^{43}$ Other courts have held that Kodak forces them to reconsider the question of market power in aftermarkets by conducting a factual inquiry into the "commercial realities," including market imperfections, faced by consumers. ${ }^{44}$ The Kodak opinion lends itself to

than one rate of return. Hovenkamp, Federal Antitrust Policy $\$ 14.1$ at 516 (cited in note 1). If the favored purchaser is paying a competitive price, then the disfavored purchasers must be paying a price higher than the competitive price. "For this reason, the ability to price discriminate is evidence that the seller has a certain amount of market power. ${ }^{\prime}$ Id $\S$ 14.1 at 517.

40 $112 \mathrm{~S} \mathrm{Ct}$ at 2086. Note that the Court here seems to have in mind a "separating equilibrium." See Douglas G. Baird, Robert H. Gertner, and Randall C. Picker, Game Theory and the Law 140-47 (Harvard, 1994). Given certain conditions, one party can ask a question or make an offer to another party that will force the second party to reveal information about themselves that otherwise might remain private, nonverifiable information. Id at 147. In the Kodak context, the Court posited that if there were two types of consumers, sophisticated and unsophisticated, Eastman Kodak might deliberately price its products so that sophisticated consumers would not consider them, in order to deal only with unsophisticated consumers.

41 The Ninth Circuit's Kodak opinion was the first by a court of appeals to reject arguments such as Kodak's because of the possibility of market imperfections. See Kodak, 112 S Ct 2072, 2100 (Scalia dissenting) (citations omitted). Of course, if aftermarkets could be defined as "relevant markets," 100 percent market share, such as that possessed by Kodak in its aftermarket, would aid plaintiffs in establishing antitrust liability. Hovenkamp, Federal Antitrust Policy $\$ 3.1$ at 81-82 (cited in note 1).

${ }^{42}$ Kodak, $112 \mathrm{~S} \mathrm{Ct}$ at 2086-88.

43 See Mr. Sprout, Inc. $v$ United States, 8 F3d 118, 125 (2d Cir 1993), cert denied, 114 S Ct 2674 (1994).

${ }^{44}$ See, for example, Allen-Myland, Inc. v IBM Corp, 33 F3d 194 (3d Cir), cert denied, $115 \mathrm{~S} \mathrm{Ct} 684$ (1994) (stating that Kodak may require consideration of market imperfections). 
both interpretations, and they are not entirely inconsistent. But both views are problematic: one approach fails to address how a court should classify economic arguments as permissible factbased arguments or as impermissible theory. The other approach advocates an open-ended inquiry that may be difficult for courts to undertake and may prove puzzling to businesses trying to organize their affairs.

1. Mr. Sprout: the problem of separating "factual data" from "economic theory."

In Mr. Sprout, Inc. $v$ United States, ${ }^{45}$ the Second Circuit interpreted Kodak to say that "summary judgment on the sole basis of economic theory" rather than "factual data" is inappropriate, but that Kodak is inapplicable when defendants supply factual data. ${ }^{46}$ As a result, in the Second Circuit a defendant need only supply factual data to defend against a "tying" claim. ${ }^{47}$

In $M r$. Sprout, the plaintiff alleged that intervenor Conrail was illegally imposing surcharges on certain routes to discourage the plaintiff from filing damage claims. ${ }^{48}$ Conrail claimed it needed the surcharge to defend against the particular plaintiffwholesalers' frequent damage claims. ${ }^{49}$ In order to subject Conrail to statutory "reregulation," plaintiff sought to demonstrate, as a threshold matter, that Conrail had market power over the shippers. ${ }^{50}$ In response Conrail supplied statistics indicating

458 F3d 118 (2d Cir 1993), cert denied, 114 S Ct 2674 (1994).

${ }^{46} 8 \mathrm{~F} 3 \mathrm{~d}$ at 125.

47 A "tie-in" or "tying" arrangement is a sale or lease of one product (the "tying" product) on the condition that the buyer take a second product (the "tied" product) as well. Hovenkamp, Federal Antitrust Policy $\S 10.1$ at 351 (cited in note 1). Tying arrangements can violate $\S 1$ of the Sherman Act, 15 USC $\S 1$ (1988 \& Supp 1990); 33 of the Clayton Act, 15 USC § 14 (1988); and $\S 5$ of the Federal Trade Commission Act, 15 USCA § 45 (1988 \& Supp 1995). See generally Hovenkamp, Federal Antitrust Policy §§ 10.1, 10.3 at 351 \& $\mathrm{n} \mathrm{1,361-62.} \mathrm{In} \mathrm{order} \mathrm{to} \mathrm{find} \mathrm{an} \mathrm{illegal} \mathrm{tying} \mathrm{arrangement,} \mathrm{courts} \mathrm{must} \mathrm{find}$ "sufficient [market] power" in the tying product's market to restrain competition in the market being tied. Id $\S 10.1$ at 351 n 3, citing Digidyne $v$ Data General Corp, 734 F2d 1336, 1338 (9th Cir 1984) (enunciating "perhaps the most frequently cited test"). Two other requirements of this test are that: (1) "the scheme in question involves two distinct items and provides that one (the tying product) may not be obtained unless the other (the tied product) is also purchased"; and (2) "a 'not insubstantial' amount of commerce is affected by the arrangement." Id.

48 F3d at 122 .

49 Id at 121.

so Id at 123. According to the plaintiff, Conrail illegally charged competing distributors higher transport rates, in order to take over the potato wholesale business itself. Id at 124 . 
that the ratio of its revenues to its costs was similar to that of other railroads in competitive markets. ${ }^{51}$ Because economic theory predicts that firms in competitive markets price their goods differently than monopoly firms, ${ }^{52}$ the court held the evidence that Conrail priced its goods in a manner similar to firms in competitive markets sufficient to show that it operated in a competitive market, and thus did not possess the market power required to find an antitrust violation. ${ }^{53}$ The court limited Kodak to cases in which defendants do not offer factual data, deciding that no inquiry into the market imperfections discussed in Kodak was necessary. ${ }^{54}$

Presumably, had the court decided that Conrail's argument was based "solely on economic theory," applied. But Kodak cannot mean that a defendant's offer of any factual data makes Kodak irrelevant. Like Conrail, Kodak offered factual evidence that it participated in a competitive primary market. ${ }^{56}$ But in Kodak, the Supreme Court rejected Kodak's argument that economic theory alone could prove that a competitive primary market indicated a competitive aftermarket. ${ }^{57}$

In contrast, by ruling that actual cost-revenue ratios could demonstrate that Conrail did not possess market power, the court in Mr. Sprout used economic theory to establish the link between the market in question and other competitive markets. Both Kodak's argument about the links between primary markets and aftermarkets and Conrail's argument reveal how courts dealing with market power rely to some extent on economic theory. ${ }^{58}$ Thus, $M r$. Sprout requires courts to separate fact from the-

51 Id.

52 Theory suggests that firms produce the quantity at which the marginal cost of producing an additional unit equals the marginal revenue gained by selling that unit in the market. In a competitive market, that marginal revenue equals the price of the good, which does not change due to a single firm's behavior, since competitors will continue to sell at that price. By contrast, monopolists, who have no competitors, can alter the price of the good in the market in relation to the quantity that they produce. Thus monopolists can maximize their profits by reducing the quantity they produce and raising prices. See Hovenkamp, Federal Antitrust Policy $\$ \S 1.1-1.2$ at 8-14 (cited in note 1).

53 Mr. Sprout, 8 F3d at 124-25.

or Id at 125.

s5 Id.

s5 Kodak, 112 S Ct at 2081 n 10.

57 Id at 2084.

ss Kodak's argument depends on the theory that perfectly informed consumers understand, calculate, and purchase based on the relationships between primary markets and aftermarkets. See also Parts and Electric Motors, Inc. $v$ Sterling Electric, Inc., 866 F2d 228, 236 (7th Cir 1988) (Posner dissenting) (arguing that a lack of market power in the primary market necessarily forecloses the possibility of abusing market power in the 
ory and to decide which theories are permissible. However, the court supplied no method for drawing these distinctions.

Of course, defendants can still use economic theory as well as factual data to obtain summary judgment. But Mr. Sprout requires courts to distinguish factual data from economic theory to decide whether Kodak applies. ${ }^{59}$ Then, as the comparison between Kodak's argument and the defendant's argument in $\mathrm{Mr}$. Sprout suggests, courts must decide which economic theories defendants may use to obtain summary judgment, and which they cannot. ${ }^{60}$ Finally, courts must weigh the theory advanced, if the theory is ruled permissible, against contrary facts. ${ }^{61}$ This balancing will be difficult for courts, summary judgment will become harder to obtain, and judicial efficiency will suffer. ${ }^{62}$

In view of these wide implications, the court in Mr. Sprout effectively decided that Kodak did not apply to the specific economic theory used by the defendant in $M r$. Sprout: cost-revenue ratios. But for other economic theories, future courts will again have to separate economic theory from factual data, decide on the permissibility of the theory, and then possibly weigh theory versus facts. ${ }^{63} M r$. Sprout and Kodak have left lower courts with no guidance on how to perform these tasks. ${ }^{64}$ As a result lower

aftermarket). The defendant's argument in $M r$. Sprout depends on the theories that: (1) the relationship between price, marginal cost, and marginal revenue for a firm in a competitive market is different than that for a monopoly; and (2) to the extent that the ratio between two firms' costs and revenues are similar, they must both be either firms in competitive markets or monopolies. See Hovenkamp, Federal Antitrust Policy §§ 1.1-1.2 at 8-14 (cited in note 1).

${ }_{59}$ See Hovenkamp, Federal Antitrust Policy $\$ 16.8$ at 581 (cited in note 1) (suggesting that, after Kodak, courts will have to weigh economic theory versus contrary fact in order to decide summary judgment motions). Weighing fact against theory necessarily requires separating the two.

${ }^{60}$ See id $\S 16.8$ at 580-81. Hovenkamp notes that after Kodak, courts considering summary judgment motions will effectively have to ask two questions: (1) "[W] hen is an economic theory so robust that claims contrary to it must be regarded as in some sense 'implausible?" and (2) "When the economic theory is robust, what extra factual showing is necessary before plaintiffs can proceed with a claim inconsistent with the theory?" Id § 16.8 at 580. According to Hovenkamp, neither Matsushita (an important, pre-Kodak antitrust summary judgment case) nor Kodak is very helpful in deciding which economic theories may be used to obtain summary judgment. Id $\S 16.8$ at 581 .

${ }^{61} M r$. Sprout, 8 F3d at 118.

62 See Schwarzer and Hirsch, 45 Hastings $\mathrm{L} J$ at 10-12 (cited in note 10) (expressing fear that Kodak will lead lower courts to require parties moving for summary judgment to supply factual evidence disproving the opponent's case; courts would thus become more wary of movants' arguments, resulting in a decline in the use of summary judgment).

$\varpi$ Hovenkamp, Federal Antitrust Policy $\S 16.8$ at 580-81 (cited in note 1).

${ }^{64}$ See id $\S 16.8$ at 581. 
courts may adopt unpredictable and incompatible approaches, effectively raising the standard for summary judgment. ${ }^{65}$

2. Allen-Myland: the difficulties of an open-ended inquiry into information-driven market imperfections.

Some courts have decided that Kodak forces them to conduct a factual inquiry into the "commercial realities" faced by consumers in order to define market power. ${ }^{66}$ In one case, AllenMyland, Inc. $v$ IBM Corp ${ }^{67}$ the Third Circuit read the Kodak decision as denying summary judgment based on the existence of market imperfections such as high information and switching costs. $^{68}$ Thus the Third Circuit investigated whether the case involved "locked-in" consumers and whether this created market power. ${ }^{69}$ Defendant IBM supplied evidence of competing computers at trial, but unlike in $M r$. Sprout, the court held defendant's use of factual data insufficient to escape Kodak. ${ }^{70}$ In AllenMyland, the court used Kodak to direct the method by which such data should be evaluated. This inquiry into "commercial realities" may be problematic. Under this rubric, judges and juries must consider fairly complex anecdotal evidence. ${ }^{71}$ This discretionary approach may provide little notice for businesses and administrative headaches for future courts. ${ }^{72}$

6s Schwarzer and Hirsch, 45 Hastings $L \mathrm{~J}$ at 10-12 (cited in note 10).

${ }^{66}$ See, for example, Sunshine Cellular $v$ Vanguard Cellular Systems, Inc., 810 F Supp 486, 494 (S D NY 1992).

6733 F3d 194 (3d Cir), cert denied, 115 S Ct 684 (1994).

${ }^{63}$ See id at 205. Switching costs are expenses that consumers incur when moving from one brand or product to another. See Joseph Kattan, Market Power in the Presence of an Installed Base, 62 Antitrust L J 1, 11 (1993). To the extent that switching costs are prohibitively high, consumers are said to be "locked-in." Id at 5. An OEM can exploit consumers (1) only if they do not anticipate the higher-than-competitive prices they will be charged, and (2) only to the extent they are locked in by switching costs. Parts and Electric Motors, Inc. $v$ Sterling Electric, Inc., 866 F2d 228, 236 (7th Cir 1988) (Posner dissenting). See also Kodak, $112 \mathrm{~S}$ Ct at 2087. Furthermore, OEMs may be penalized by future consumers if the consumers learn of this type of past behavior. Parts and Electric Motors, $866 \mathrm{~F} 2 \mathrm{~d}$ at 236. Thus, at least two commentators have argued that market power can exist in product aftermarkets "only when information costs are high for consumers with high switching costs." Michael W. Klass and Richard T. Rapp, Litigating the Key Economic Issues Under Kodak, Antitrust 14-16 (Spring 1993).

${ }^{69}$ Allen-Myland, 33 F3d at 205.

${ }^{70}$ Id at 205-06.

"Note that the complexity of one antitrust case led a court to decide that a jury would not be permitted to hear the case, in effect creating a "complexity exception" to the Seventh Amendment. See In re Japanese Electronic Products Antitrust Litigation, 631 F2d 1069, 1084-86 (3d Cir 1980).

${ }^{72}$ See Jacobs, 79 Minn L Rev at 28-29 (cited in note 10) (stressing business's need for clear guidance, not rules with an "ambiguous, qualitative character"). 
In Allen-Myland, both plaintiff Allen-Myland, Inc. ("AMI") and defendant IBM upgraded mainframe computers originally built by defendant IBM. ${ }^{73}$ Although AMI bought its upgrade parts directly from IBM, AMI prospered by performing upgrades with less downtime than defendant IBM. In 1980, however, when IBM introduced its next generation of mainframes, IBM prevented AMI and other independent service providers from obtaining the parts necessary to perform upgrades on these models. ${ }^{74}$ In response, AMI filed a complaint alleging, among other things, that IBM had violated $\S 1$ of the Sherman Act, which prohibits "combination[s] [and other means] in restraint of trade." ${ }^{275}$ AMI claimed that, by these practices, IBM illegally forced consumers to purchase their aftermarket services from IBM rather than from potentially cheaper competitors. ${ }^{76}$

Consumers would suffer from IBM's practices only to the extent that IBM possessed market power sufficient to force consumers to use IBM mainframes or go without; as a result, the Third Circuit panel investigated the degree to which IBM mainframe users, possessing significant applications software and databases, could move such applications and data to smaller computers, and were thus not actually "locked in" to IBM mainframes. The Third Circuit panel advised that, to analyze the effects of this lock-in, the district court should determine the percentage of existing mainframe users who were unable to move to a new system by prohibitively high switching costs. ${ }^{77}$ The court stated that the higher the percentage of locked-in consumers, the more likely that IBM could charge monopoly prices in the largescale mainframe market, and the less likely that IBM would be constrained by the existence of other types of computers. ${ }^{78}$ In accordance with this reasoning, "[t]he [district] court may, after considering the evidence and the nature of the market, exercise its discretion and reduce IBM's market share by a number great-

73 Allen-Myland, 33 F3d at 198-99. The mainframe computers in question were physically large machines that required tailoring to the needs of specific users. Id.

${ }^{4}$ The new mainframes were sold under a pricing system that bundled IBM installation labor together with replacement parts necessary for future upgrades. Id. Additionally, IBM eliminated most parts sales to independent service providers, making a few sales at prohibitively high prices. Id. Furthermore, under the terms of a mainframe sale, after an upgrade, any used parts recovered were IBM's property. Id. Consequently, neither new nor used parts were available to independent service providers.

${ }^{75}$ See id; 15 USC $\$ 1$.

${ }^{76}$ Allen-Myland, 33 F3d at 199.

77 Id at $206 \mathrm{n} 15$.

78 Id. 
er than zero percent but less than the full extent [100 percent] of the market for other types of computers." 79

In effect, the Third Circuit read Kodak to promote an inquiry into the possibility of switching costs, ${ }^{80}$ and attempted to provide the district court instruction on how to analyze locked-in consumers to determine market power. ${ }^{81}$ The Court of Appeals indicated that the effects of switching costs should be considered in market definition-with courts adopting a narrower or broader

79 Id. For an example of how this rule would work, suppose that IBM had an 80 percent share of the market for mainframes, and that the market for mainframes was equally large as the market for other computers. Depending on its impression of the ease of switching from mainframes to other computers, the district court could adjust IBM's market share to 40 percent (finding it quite easy or cheap to switch), 80 percent (impossible to switch), or something in between. The math would run as follows: suppose $\mathrm{X}$ represents total industry sales in the mainframe market, and $Y$ represents total industry sales in the market of small computers. The district court should determine a number $\mathrm{Z}$ from 0 to 100 percent representing how much of the market of small computers should be included in defining IBM's market. The easier to switch, the higher $\mathrm{Z}$ would be. If IBM has an 80 percent market share in the mainframe market, then for $Z=0$ (impossible to switch), IBM's market share is:

(its total share of the mainframe market) $\div$

( (the total size of the mainframe market) + ( (the total size of the small computer market) * (a figure $\mathrm{Z}$ representing the degree of interchangeability of small computers and mainframes) ) ) $=$

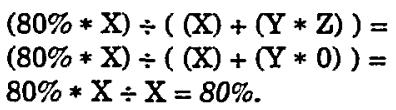

For $\mathrm{Z}=100 \%$ (complete interchangeability),

$(80 \% * \mathrm{X}) \div((\mathrm{X})+(\mathrm{Y} * \mathrm{Z}))=$

$(80 \% * X) \div((X)+(Y * 100 \%))$.

If $\mathrm{X}=\mathrm{Y}$ (the two markets are equally large), then IBM's market share is:

$(80 \% * \mathrm{X}) \div((\mathrm{X})+(\mathrm{X}))=$

$0.8 \mathrm{X} \div(2 \mathrm{X})=$

$0.4=40 \%$.

Note that for $\mathrm{Z}$ between 0 and 100, IBM's market share would be adjusted to between 80 percent and 40 percent. This calculation would be more complex if the two markets were not of the same size.

Finally, note that small changes in how the court estimates $\mathrm{Z}$ can have substantial effects on the final calculation of market share, especially if $Y$ (here, the size of the market for small computers) is much greater than $\mathrm{X}$ (here, the size of the market for mainframes).

${ }^{80}$ See note 68 , discussing the relationship between costly information and switching costs.

81 Allen-Myland, 33 F3d at 205-06. Note that, because Kodak was decided in the interim, the parties in Allen-Myland first raised the lock-in issue on appeal. Id at 205. The Court of Appeals left the question of whether to consider new issues, including the lock-in question, to the district court on remand. Id at 206. 
market, ${ }^{82}$ depending on the extent of locked-in consumers. ${ }^{83}$ If a court determined that a high percentage of consumers were locked in, then the court would define the relevant market more narrowly, and thus make it more likely that the court would find a violation of the antitrust laws. ${ }^{84}$

Allen-Myland directs district court judges to pick a number from zero to one hundred based on their impression of expert testimony, anecdotal evidence, and estimates of the number of consumers who were capable of switching products. ${ }^{85}$ Such ambiguous directions pose a danger of arbitrariness. There is no guarantee that judges will easily and accurately estimate interchangeability based on this type of evidence. ${ }^{86}$ Furthermore, businesses might lack guidance since they would face similar difficulties in assessing what courts would conclude from the available evidence. ${ }^{87}$ Judges and private actors will also have to expend resources trying to make sense of impressionistic, factspecific precedents to guide their future decisions.

Although Allen-Myland, like Kodak, concerned "complex durable goods," over the market imperfections discussed in Kodak to services. ${ }^{89}$

82 A broader market definition would have aided IBM because market power is traditionally estimated by market share (a proxy variable). Generally the higher a firm's market share in a relevant market, the more likely it is to possess market power. See Jefferson Parish Hospital District No. $2 v$ Hyde, 466 US 2, 17 (1984). Since IBM sold a fixed number of mainframes, the more the court widened the definition of the relevant market, the lower IBM's market share (IBM's sales $\div$ total relevant market sales) would have been. A lower market share implies that the firm is less likely to possess market power.

${ }_{83}$ Allen-Myland, 33 F3d at 205-06 \& $\mathrm{n} 15$.

84 See id at 205-06.

8s Id at $206 \mathrm{n} 15$.

86 See Hovenkamp, Federal Antitrust Policy $\$ 3.5$ at 105 (cited in note 1) (Judges "often ignore elasticity of supply or else have difficulty in stating the relevant concerns" when they measure market power in light of interchangeability of products.). In particular, Hovenkamp points to Fineman v Armstrong World Industries, Inc., 980 F2d 171, 20001 (3d Cir 1992), cert denied, 113 S Ct 1285 (1993), which concluded that "video tape 'magazines' of floor coverings were a relevant market because linoleum sellers wishing to purchase such videos would not find other kinds of videos a substitute." Hovenkamp, Federal Antitrust Policy $\S 3.5$ at $105 \mathrm{n} 11$. Hovenkamp criticizes Fineman as "totally ignoring the fact that someone with the equipment to videotape floor coverings could probably videotape refrigerators, sofas or farm animals, or vice-versa, with little additional investment." Id.

${ }^{87}$ See Jacobs, $52 \mathrm{Md} \mathrm{L} \mathrm{Rev} \mathrm{at} \mathrm{371-72} \mathrm{(cited} \mathrm{in} \mathrm{note} \mathrm{5)} \mathrm{(noting} \mathrm{the} \mathrm{difficulties} \mathrm{that}$ smaller firms will have in predicting what courts will make of market imperfections such as switching costs after Kodak).

${ }^{88}$ Allen-Myland, 33 F3d at 198; Kodak, 112 S Ct at 2077.

69 See Lee $v$ Life Insurance Company of North America, 829 F Supp 529, 536-39 (D RI 1993) (Student plaintiffs argued that the University of Rhode Island violated antitrust 
If judges and OEMs have found it difficult to interpret or assign numerical ratings to the interchangeability of durable goods, services will prove even more difficult to compare. ${ }^{90}$ Thus, AllenMyland's discretionary inquiry into market imperfections has serious defects. This interpretation of Kodak gives businesses little guidance ${ }^{91}$ and would be costly for courts to administer.

\section{INFORMATION AS THE KEY TO THE AFTERMARKET MONOPOLY PROBLEM}

The problem of information costs holds the key to both $K_{0}$ $d a k$ and the overall problem of aftermarket monopolies. Information gaps drove the Court's opinion in Kodak. Whether due to the cost or unavailability of information, the Court reasoned that some consumers will remain unable to estimate accurately the life-cycle costs of durable equipment. ${ }^{92}$ These information gaps can lead to aftermarket monopoly power for OEMs.

Two examples illustrate how information costs can make aftermarket monopolies possible. ${ }^{93}$ First, consider a consumer who must buy both original equipment and aftermarket products. Under the assumptions of classical economics, the consumer possesses perfect, that is costless, complete information about price and other attributes of all goods in the market. ${ }^{94}$ Thus,

laws by forcing them to buy health insurance together with their college educations; the court interpreted $K o d a k$ to authorize an inquiry into information and switching costs that might hamper students from purchasing outside insurance or attending other colleges.).

90 Courts have trouble with the concept of "elasticity of supply"-the ability of the market to supply more of a product available given a rise in price. Hovenkamp, Federal Antitrust Policy $\S 3.5$ at 105 (cited in note 1). To estimate elasticity of supply for durable goods, judges look at how much existing plants can produce, as well as the speed and expense of existing plant expansion or new plant production. See Posner and Easterbrook, Antitrust at 512 (cited in note 16), discussing FTC v Procter \& Gamble Co., 386 US 568 (1967). Courts must also decide to what extent different products' supplies are interchangeable and thus augment supply. See, for example, FTC v Owens-Illinois, Inc., $681 \mathrm{~F}$ Supp 27 (D DC), vacated, 850 F2d 694 (DC Cir 1988) (deciding that glass and plastic jars composed a single market because assembly lines for their production were interchangeable).

91 See Jacobs, $52 \mathrm{Md} \mathrm{L} \mathrm{Rev} \mathrm{at} 373$ (cited in note 5).

$12 \mathrm{~S}$ Ct at 2086.

\$3 For simplicity, both examples are grounded in the assumptions of perfect competition. However, the first model has perfect information about price, quality, and sources of supply, while the second does not. Perfect information is one of the three conditions of a perfectly competitive market in classical economics. The other two conditions are that (1) buyers and sellers must be numerous, and consequently price takers in the sense that their individual transactions do not affect the market price, and (2) the product sold by the firms in the industry must be homogeneous. Edwin Mansfield, Principles of Microeconomics 219-20 (Norton, 3d ed 1980).

94 Id. 
consumers can estimate the costs of original equipment and aftermarket needs together as if they were a single product. If the OEM tries to sell this aggregate product at higher than the equilibrium price in the market, the informed consumer will purchase elsewhere. ${ }^{95}$ As a result, Kodak-style aftermarket monopolies cannot exist in the classical economic world of perfect competition. ${ }^{96}$

By contrast, without the assumption of perfect information, the OEM can make the consumer pay prices that are higher than the market price in a world of perfect competition. For example, suppose that the consumer is at the OEM's store, and that the consumer possesses some knowledge about the OEM's products, ${ }^{97}$ but nothing, good or bad, about those of the OEM's competitor. Suppose that it costs the consumer time and effort to learn more about what is available at competitors' stores and about competitors' products. We can sum up these various costs in time and effort and call them "information costs." Because of these information costs, the OEM could charge a higher-than-

${ }_{95}$ Suppose the competitive market price for original equipment is $P$ and the competitive market price for aftermarket goods and services is $p$. Suppose also that the OEM in question overcharges for original equipment and aftermarket goods and services by margins $M$ and $m$ respectively above the competitive price. Because this is a perfect competition model, there are no information costs. Thus, consumers will buy elsewhere when:

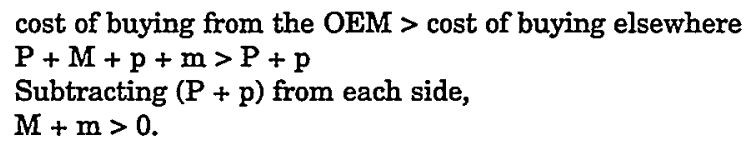

Thus, whenever the OEM in question charges any total margin on original equipment and aftermarket goods greater than zero, consumers will purchase elsewhere. Granted, those consumers who have already purchased may be stuck with the OEM if the OEM is the only maker of aftermarket goods for its product. This could result if OEMs possess intellectual property protection for the design of aftermarket products such as replacement parts. See John J. Voortman, Curbing Aftermarket Monopolization, 38 Antitrust Bull 221, 222-23 (1993). But with perfect information, new consumers will factor such an OEM's overpricing into their assessment of the OEM's original equipment.

${ }_{96}$ For a more detailed description of which departures from perfect competition must exist in order for OEMs to benefit from higher aftermarket prices, see Richard A. Posner, Economic Analysis of Law 311-13 (Little, Brown, 4th ed 1992).

${ }_{97}$ Product-specific knowledge is an important cause of switching costs. See Kattan, 62 Antitrust L J at 11-12 (cited in note 68). Consider the difficulty a Macintosh user often has making the transition to using DOS. Id.

98 "Information costs" would also include the costs a buyer would incur in estimating future aftermarket needs and the market prices of those aftermarket needs for different brands of a product. See Richard Craswell, Tying Requirements in Competitive Markets: The Consumer Protection Issues, 62 BU L Rev 661, 690-91 (1982). 
market price for the combination of the original equipment and aftermarket goods or services, so long as the margin between the market price and the price the OEM charges is less than the amount of the information costs. ${ }^{99}$ In that event, the consumer will find it less costly to pay supracompetitive prices than to incur the information costs necessary to avoid such prices.

Though simplistic, these examples illustrate the effect that information costs can have. As a result of information costs, an OEM can set prices above the competitive level, and consumers will pay those prices. The higher the information costs, the greater the ability to price above the market. This is important because the touchstone of any antitrust claim against a monopolistic firm, "market power," has been defined as "[t]he power [of a seller] to set higher than competitive prices."100

By this definition, under Kodak, courts could find market power, and thus a potential antitrust violation, whenever there are information costs. ${ }^{101}$ Since many real-world markets suffer from these defects, Kodak could lead to dramatic increases in judicial findings of market power. ${ }^{102}$ Some have argued that

s9 Suppose that the competitive price is $P$ for the original equipment and $p$ for the aftermarket goods and services, and information costs that must be incurred to purchase elsewhere are $i$. Suppose the margins by which the OEM in question charges above the competitive price are $M$ and $m$ respectively for the original equipment and the aftermarket goods and services. The consumer will purchase from the OEM in question when:

cost of buying from the OEM < cost of buying elsewhere

$P+M+p+m<P+p+i$.

Subtracting $(P+p)$ from each side,

$\mathbf{M}+\mathbf{m}<\mathbf{i}$.

Thus, when the total margin by which the OEM in question overcharges is less than the information costs that must be incurred to purchase elsewhere, the consumer will buy from the OEM in question. This method of approaching the problem proceeds from the idea that one party bases its optimization decision on the assumption that the other party will also choose the alternative that maximizes its own gain. See generally Baird, Gertner, and Picker, Game Theory and the Law at 50-57 (cited in note 40) (using a game theory approach to determine parties' optimal decision trees). The greater the information costs, the greater the ability to impose supracompetitive pricing. See Herbert Hovenkamp, Market Power in Aftermarkets: Antitrust Policy and the Kodak Case, 40 UCLA I Rev $1447,1447-49$ (1993) (In product differentiated markets, firms may possess the ability to price above the competitive level indefinitely; "the policy question becomes one of degree: how many and what kinds of deviations should be tolerated.").

${ }_{100}$ Matsushita Electric Industrial Co. v Zenith Radio Corp, 475 US 574, 590 (1986).

101 See also Robert H. Bork, The Antitrust Paradox: A Policy at War with Itself 438-39 (Free Press, 1993) (arguing that '[i]t is always possible to posit 'market imperfections' that may result in markets working contrary to the predictions of economics," and that the "imperfections" in Kodak were "both ingenious and imaginary").

162 See Hovenkamp, 40 UCLA L Rev at 1448 (cited in note 99). 
such far-reaching implications should lead the Court to overturn Kodak. ${ }^{103}$ The Court, however, should not overturn Kodak, because the Court's concern with information costs can have substantial beneficial effects, and represents a recognition of the important role that information plays in markets. ${ }^{104}$ Consistent with Kodak, a rule that promotes disclosure of information between OEMs and buyers would greatly diminish the ill effects on consumers of imperfect information. ${ }^{105}$ The problem of information costs can be reduced by creating incentives for OEMs and buyers to share information, thereby creating markets that more closely resemble the model of perfect information.

\section{OEMS THAT OFFER AFTERMARKET PARTS AND SERVICE CONTRACTS AT COMPETITIVE PRICES FOR THE REASONABLE LIFETIME OF DURABLE EQUTPMENT SHOULD BE EXEMPTED FROM KODAK ANTITRUST LIABILITY}

\section{A. The Proposal and Its Roots}

Courts should fashion a rule exempting OEMs from aftermarket antitrust liability where the OEM offers aftermarket supply contracts at the time of original equipment purchase. This rule creates an incentive for OEMs to provide unsophisticated consumers the information-the life-cycle cost of durable equipment-to make those consumers more "sophisticated."106 The rule is consistent with Kodak in denying antitrust relief to sophisticated consumers-the Court in that case agreed that sophisticated consumers do not need protection from market imperfections. ${ }^{107}$ Lower courts need only assess whether or not the

103 One writer has advocated overturning Kodak because, he argues, the market power it defines is qualitatively different than previous definitions of market power. See Thomas C. Arthur, The Costly Quest for Perfect Competition: Kodak and Nonstructural Market Power, 69 NYU L Rev 1, 76 (1994).

${ }_{104}$ See Spivack and Ellis, 62 Antitrust L $J$ at 206 (cited in note 14) (welcoming the Court's balanced decision to make market imperfections such as information costs relevant to antitrust analysis without "a wholesale rejection of economic theory"); Comment, Rewriting the Law of Resale Price Maintenance: The Kodak Decision and Transaction Cost Economics, 143 U Pa L Rev 321, 360 (1994) (noting the beneficial effects that "transaction cost economics"-focusing on market imperfections such as information, bargaining, and switching costs - as recognized in Kodak can have for resale price maintenance, a branch of antitrust law).

${ }_{105}$ For a discussion on how to choose rules that induce parties to disclose information efficiently, see Ian Ayres and Robert Gertner, Filling Gaps in Incomplete Contracts: An Economic Theory of Default Rules, 99 Yale L J 87, 93 (1989).

106 Kodak, 112 S Ct at 2086.

107 Id. 
consumer made a "sophisticated" decision based on the difference between the price of aftermarket supply contract and the market price for such a contract.

This Section's logic borrows from previous work in the field of products liability, showing that warranties effectively convey information. ${ }^{108}$ Where consumers are uninformed as to product quality, legally enforceable warranties can make a seller's statements about product quality more credible, especially when the quality in question can be verified cheaply after the fact. ${ }^{109}$ Thus, legal rules can provide sellers with incentives to make full disclosures. ${ }^{110}$

Much as warranty contracts can convey information to consumers, OEMs can reveal information about aftermarket costs to consumers via aftermarket supply contracts. Professors Ian Ayres and Robert Gertner have argued that contract default rules should be chosen so as to "penalize" the more informed party, thus inducing that party to reveal its information in contract bargaining and formation. ${ }^{111}$ This theory, as applied to the problem of aftermarket costs, resembles a penalty default for OEMs: firms can avoid the penalty by revealing the types of information that concerned the Kodak Court, such as life-cycle price information, in aftermarket supply contracts. ${ }^{112}$ An exemption from antitrust liability under Kodak for OEMs that offer aftermarket supply contracts creates incentives for disclosure of

${ }^{208}$ Theorists argue that warranty terms provide information to consumers about mechanical reliability of the product. Akerlof, $84 \mathrm{Q} \mathrm{J}$ Econ at 499 (cited in note 13); Spence, Market Signaling at 88-90 (cited in note 13). See also Bryant and Gerner, $12 \mathrm{~J}$ Consumer Aff at 32, 45-46 (cited in note 13); Gerner and Bryant, $15 \mathrm{~J}$ Consumer Aff at 77-86 (cited in note 13) (finding empirical evidence of substantial uniformity in warranty terms, such as duration of coverage, that enable cross-brand comparison). Writers have also argued that the cost of a warranty, emphasized by its price and any exclusions, provides an extremely important signal for consumers, since more reliable products cost less for the manufacturer to guarantee. See Spence, Market Signalling at 88-90; Note, 88 Colum $L$ Rev at 1061-62 (cited in note 12).

${ }^{100}$ See Sanford J. Grossman, The Informational Role of Warranties and Private Disclosure About Product Quality, 24 J I \& Econ 461, 462-63 (1981).

"10 Id. Conversely, if consumers cannot enforce rights against producers for misrepresentations, then consumers will remain uninformed, since they will not be able to rely on producers' representations. Id. Consumers need credible information on risks in order to make efficient purchases. See Michael Spence, Consumer Misperceptions, Product Failure and Producer Liability, 44 Rev Econ Stud 561, 562-64 (1977). One writer has argued that warranties successfully convey the necessary information to buyers via the price mechanism, if such warranties are priced separately from the purchased equipment. See Note, 88 Colum L Rev at 1062-63 (cited in note 12).

I11 Ayres and Gertner, 99 Yale $\mathrm{L} J$ at 91 (cited in note 105).

112 Kodak, $112 \mathrm{~S}$ Ct at 2085, 2085-86 n 20. 
information that helps both consumers and courts. ${ }^{113}$ By fostering efficient disclosures, this rule meets Kodak's concerns about unsophisticated consumers and mirrors the logic behind consumer products warranties and contract default rules.

\section{B. The Mechanics of the Proposal}

1. The price mechanism will convey information to consumers.

The price of aftermarket supply contracts would reflect the life-cycle pricing data that concerned the Kodak Court.114 To fairly price these contracts, OEMs would have to calculate the aftermarket costs of the equipment, ${ }^{115}$ including estimates of future product maintenance and repair. ${ }^{116}$ Although the price of such a contract would not include costs specific to the individual consumer, the contract price would likely provide information that consumers could weigh in addition to what they know themselves. Furthermore, if OEMs offered lifetime aftermarket supply contracts priced separately from durable equipment itself, then consumers could make better-informed decisions about which product to buy and whether or not to purchase the aftermarket goods or services in advance. ${ }^{117}$ Consumers could gather the information necessary to make informed decisions by comparing the prices and durations of the contracts. Consumers could infer from the prices of these contracts, for example, that a copy machine with a cheaper aftermarket supply contract will be cheaper to operate and maintain. ${ }^{118}$ Based on the price of the contract, consumers could also decide, given their own individual circumstances, whether or not they could maintain and operate the equipment more cheaply on their own. ${ }^{119}$

\footnotetext{
${ }_{113}$ See Ayres and Gertner, 99 Yale L J at 124 (cited in note 105) (advocating the use of legal formalities and penalty defaults to elicit information in contracts, thereby lowering courts' subsequent decision making costs).

${ }^{114}$ Kodak, 112 S Ct at 2085, 2085-86 n 20.

115 Producers of durable equipment currently calculate some risks and costs of their products after initial sale, such as the cost of injuries to consumers due to product defects. See, for example, Reynold M. Sachs, Products Liability: An Economic View, Trial 48, 50 (Mar 1978).

${ }^{116}$ See Note, 88 Colum L Rev at 1062-63 (cited in note 12).

117 The logic behind this Section is similar to one commentator's products liability proposal regarding imperfect warranty information. See id at 1063-68.

${ }^{118}$ See Spence, Market Signaling at 88-90 (cited in note 13).

119 Consumers will choose to "self-insure" in this manner for two reasons: (1) if a producer cannot distinguish high- and low-risk consumers, the cost of coverage for any given risk will represent the average cost for all consumers. Thus if an individual's expected
} 
2. Market forces will substantially enforce accurate aftermarket supply contract prices.

OEMs would find it difficult to deceive consumers by underor overpricing these contracts because these contracts are largely self-regulating. Market forces and existing law constrain OEMs' ability to set prices above or below market rates. For example, an OEM might try to underprice such a contract to make consumers think that its products break down less frequently or require less service to use. ${ }^{120}$ But if an OEM underprices such a contract, consumers will buy more contracts than if they were priced accurately. ${ }^{121}$ As a result, OEMs will have to provide more aftermarket goods and services at prices lower than the accurate price, while receiving less money per contract. ${ }^{122}$

Similarly, an OEM might raise the price of contracts for aftermarket goods and services to either gouge consumers or deter them from buying these contracts. But in response, consumers could infer that the higher prices reflect the shoddy quality of the original equipment; leading to fewer total sales. ${ }^{123}$ Market forces limit both under- and overpricing of these contracts.

Of course, market constraints might not completely balance out the incentive to under- or overprice. But a manufacturer who underprices contracts to supply aftermarket goods may be liable for predatory pricing under $\S 2$ of the Sherman Act or under state unfair competition laws. ${ }^{124}$ Moreover, manufacturers who

costs are below average for the risks covered, it will be cheaper for that individual not to purchase coverage; and (2) it may be generally cheaper for consumers of a given product to avert the harm caused by the risk themselves rather than contract for coverage. See Note, 88 Colum L Rev at 1063 n 29 (cited in note 12), citing Priest, 90 Yale L J at 1307-19 (cited in note 12).

${ }^{120}$ See Note, 88 Colum L Rev at 1066 (cited in note 12).

121 The law of supply and demand specifies that, given a downward-sloping demand curve (usual in both the real world and the world of perfect competition), when price drops consumers will buy more of a given product. See Hovenkamp, Federal Antitrust Policy $\$ 1.1$ at $4-5$ (cited in note 1). See also Note, 88 Colum L Rev at 1066 (cited in note 12).

${ }^{122}$ Hovenkamp, Federal Antitrust Policy $\S 1.1$ at 4-5 (cited in note 1).

${ }^{123}$ See Note, 88 Colum L Rev at 1065 (cited in note 12). See also Alan Schwartz and Louis L. Wilde, Imperfect Information in Markets for Contract Terms: The Examples of Warranties and Security Interests, 69 Va L Rev 1387, 1396 (1983) (Consumers use a warranty's price and the extent of its coverage to gauge the quality of a firm's products.).

124 See Note, 88 Colum L Rev at 1066 n 36 (cited in note 12). Section 2 of the Sherman Act prohibits "predatory pricing"-selling goods or services below cost. See 15 USC § 2 (1988 \& Supp 1990). See also Phillip Areeda and Donald F. Turner, Predatory Pricing and Related Practices Under Section 2 of the Sherman Act, 88 Harv L Rev 697, 697 (1975). In addition, an OEM selling an aftermarket supply contract below cost may also be liable 
deliberately overprice their aftermarket goods and services contracts to exploit customers later would still be subject to Kodak to the extent that such purchases were not made by "sophisticated" buyers. ${ }^{125}$

\section{Potential problems can be resolved.}

Potential pitfalls to aftermarket supply contracts can be avoided. First, some might question whether OEMs could offer contracts to supply aftermarket goods and services where the prices and quantities required might be unknowable. While this is a realistic concern, the manufacturer certainly possesses more relevant knowledge about the product than the consumer prior to purchase. Certainly, manufacturers can and do estimate some unknown costs. ${ }^{26}$

Consumers who estimate their future aftermarket costs to be higher than average may be more likely to buy aftermarket supply contracts, but this should be a minor problem. This phenomenon, termed "adverse selection," has usually been associated with insurance; when a seller of insurance cannot distinguish between more and less risky purchasers, those who pose the worst risks will buy insurance disproportionately (consequently distorting its price and deterring others from purchasing it). ${ }^{127}$ Opponents of this rule might argue that, as with insurance contracts, consumers who think they are more likely to need aftermarket goods or services will be more likely to purchase aftermarket supply contracts, distorting the price of aftermarket supply contracts just as in the insurance context. ${ }^{128}$

But adverse selection does not present overwhelming difficulties for two reasons. First, like insurance contracts, to the extent

under state unfair competition laws. See Rudolf Callmann, 1A The Law of Unfair Competition, Trademarks and Monopolies $\S 7.53$ at 181-85 (Callaghan, 4th ed 1981 \& Supp 1994).

${ }^{125}$ See Kodak, $112 \mathrm{~S} \mathrm{Ct}$ at 2086-88.

${ }^{126}$ Note that manufacturers already estimate such unknowable risks as product accident costs. See Sachs, Trial at 50 (cited in note 115). Some commentators justify strict liability rules in products liability on the ground that manufacturers can estimate such risks better than consumers. See Sigmund A. Horvitz and Louis H. Stern, Liability Rules and the Selection of a Socially Optimal Production Technology, 7 Intl Rev L \& Econ 121, 125-26 (1987). See also David G. Owen, Punitive Damages in Products Liability Litigation, 74 Mich L Rev 1257, 1258 (1976) (noting that manufacturers have "virtually exclusive access" to information on some product risks).

${ }^{127}$ Note, 88 Colum L Rev at 1067 (cited in note 12), citing Hal R. Varian, Microeconomic Analysis 293 (Norton, 2d ed 1984).

${ }_{128}$ Id. 
that adverse selection is due to some misuse or overuse of the equipment, ${ }^{129}$ the contract can specify such reasons as grounds for cancellation or curtailment of the contract. ${ }^{130}$ Second, unlike the insurance scenario, consumers' knowledge about themselves may be relatively unimportant compared to OEM's' knowledge about their equipment; because consumers weigh information the manufacturer conveys together with what they know about themselves, if the former is much larger than the latter, the effects of individualized information will be relatively small. ${ }^{131}$

United States antitrust laws would not prohibit these contracts. ${ }^{132}$ By merely offering these contracts, OEMs do not condition sale of the original equipment on sale of the contract to supply aftermarket goods and services, or vice versa. ${ }^{133}$ More importantly, two circuit courts, ${ }^{134}$ as well as Justice Scalia's dissent in Kodak, ${ }^{135}$ indicate that the contracts in question are legal under antitrust law.

Finally, opponents of these contracts may argue that the contracts address antitrust problems by creating contract problems. However, courts are generally better at solving contract problems. ${ }^{136}$ As Allen-Myland demonstrates, Kodak leaves lower courts making impressionistic decisions about how to handle market imperfections due to information costs. ${ }^{137}$ Regardless of

129 This type of bias is more properly called "moral hazard": the phenomenon in which the purchase of insurance encourages its purchaser to take risks he or she would otherwise avoid. See Priest, 90 Yale L J at 1313-14 (cited in note 12).

130 See id at 1314 (noting that producers and consumers can and do contract around the problem of moral hazard), citing Isaac Ehrlich and Gary S. Becker, Market Insurance, Self-Insurance, and Self-Protection, $80 \mathrm{~J}$ Pol Econ 623, 641-43 (1972).

131 See Note, 88 Colum L Rev at 1063 n 29 (cited in note 12).

132 The Sherman Act, 15 USC § 1 (1988 \& Supp 1990), prohibits some tying arrangements. See note 47 .

${ }_{133}$ One of the requirements to find an illegal tie between two products (such as original equipment and its supply contract) is that "the scheme in question involves two distinct items and provides that one (the tying product) may not be obtained unless the other (the tied product) is also purchased." Hovenkamp, Federal Antitrust Policy $\$ 10.1$ at 351 n 3 (cited in note 1), quoting Siegel $v$ Chicken Delight, Inc., 448 F2d 43, 47 (9th Cir 1971).

124 With respect to antitrust tying law, lower courts have favorably received similar aftermarket contracts. Service \& Training, Inc. v Data General Corp, 963 F2d 680, 687-88 (4th Cir 1992) (decided just before Kodak); Amerinet, Inc. v Xerox Corp, 972 F2d 1483, 1499-1500 (8th Cir 1992), cert denied, 113 S Ct 1048 (1993) (decided just after Kodak).

135 S Ct at 2095 (Scalia dissenting).

${ }_{135}$ See, for example, Lon L. Fuller, Consideration and Form, 41 Colum L Rev 799, 801-02 (1941) (stressing that the forms required by contract law force parties to "channel" their intentions in a manner that courts can handle).

137 Allen-Myland, 33 F3d at 206 n 15 (suggesting that, depending on how easy it was for consumers to switch from mainframes to smaller capacity computers, the District 
the effect on courts, however, this rule creates much clearer guidelines for OEMs. The following Section more fully describes the benefits of the proposed rule.

\section{THE BeNEFITS OF THE RULE}

\section{A. Exempting OEMs That Help Reduce the Effect of Information Gaps Conserves Social Resources}

A rule that exempts OEMs from aftermarket liability when they offer fairly priced contracts to supply aftermarket goods and services for the reasonable lifetime of durable equipment conserves social resources. Such a rule makes life simpler for OEMs. Additionally, this rule enables courts to address a central concern of Kodak, the "commercial realities" faced by consumers, ${ }^{138}$ while conserving judicial resources.

1. The rule conserves private resources by giving OEMs guidance.

With this rule courts define clear legal boundaries for OEMs in aftermarket sales. The Supreme Court and previous commentators have emphasized the value businesses place on increased certainty in antitrust law. ${ }^{139}$ The rule would provide OEMs with a for compliance: offer lifetime aftermarket goods and services at a fair price, and you need not worry about Kodak-type liability. By contrast, the Allen-Myland approach forces businesses to assess how easy or difficult it is for their customers to shift to other products. ${ }^{140}$ With that estimate of interchangeability, businesses would have to revise their estimated market shares. ${ }^{141}$ Even once they had determined their revised market shares, they would still have to predict how high a share would render them liable under the antitrust laws. ${ }^{142}$

Court should reduce IBM's market share in mainframes "by a number greater than zero percent but less than the full extent of the market").

${ }^{138} \mathrm{Kodak}, 112 \mathrm{~S} \mathrm{Ct}$ at 2085-87.

${ }^{139}$ See United States v Topco Associates, Inc., 405 US 596, 607 (1972), quoting Northern Pacific Railway Co. $v$ United States, 356 US 1, 5 (1958) (noting that the principle of per se unreasonableness "makes the type of restraints which are proscribed by the Sherman Act more certain to the benefit of everyone concerned"); Robert Pitofsky, In Defense of Discounters: The No-Frills Case for a Per Se Rule Against Vertical Price Fixing, 71 Georgetown L J 1487, 1489 (1983) ("[T]here is a virtue in telling businessmen accurately and precisely the location of legal limits on business conduct.").

${ }^{140}$ See Allen-Myland, 33 F3d at 206 n 15 . See also text accompanying note 87.

${ }^{141}$ See Allen-Myland, 33 F3d at 206 n 15.

${ }^{142}$ Tying law seems to require a 30 percent share of a properly defined market in 
Furthermore, the proposed rule would address concerns that "innocent" firms in markets with information imperfections could fall victim to consumers taking advantage of Kodak. ${ }^{143}$ Under Kodak, plaintiffs could possibly make claims against OEMs that neither created nor intentionally exploited information costs in their aftermarkets. Under the rule advocated here, innocent firms could avoid liability simply by disclosing the required information in the contract prices of lifetime parts, service, and supplies. Thus the rule can help avert legal outcomes that at least one commentator has argued would not be "fair."

2. The rule conserves judicial resources.

After Kodak was decided, commentators predicted that it would raise the level of proof necessary to obtain summary judgment. ${ }^{145}$ As a result, Kodak generated fears of a great increase in the judicial workload. ${ }^{146}$ Additionally, at least one writer has noted the difficulties that issues in Kodak may present for juries. ${ }^{147}$

A rule that exempts OEMs that convey useful information by offering contracts for lifetime aftermarket goods and services should make it easier for courts to grant summary judgment. ${ }^{148}$ In cases where aftermarket supply contracts were offered, courts would simply inquire whether the prices on such contracts were fair at the time they were offered. But because OEMs will pos-

order to prove market power. Hovenkamp, Federal Antitrust Policy $\$ 3.7$ at 120 (cited in note 1). But note that under Allen-Myland, firms would still have to assess the interchangeability of their products on a scale of 0 to 100 percent, then weigh the relative sizes of the product markets that may be interchangeable. See Allen-Myland, 33 F3d at $206 \mathrm{n} 15$. A small error in estimating from 0 to 100 percent could easily push a firm above or below the 30 percent figure. For an example of the math involved, see note 79 .

${ }^{143}$ See Jacobs, $52 \mathrm{Md} \mathrm{L} \mathrm{Rev} \mathrm{at} 371$ (cited in note 5) (worrying that Kodak broadly interpreted could imperil "small firms that have neither generated nor abused the imperfections in their market[s]").

14 Id at 371-72.

${ }^{145}$ See Judy L. Whalley, Robin P. Rosen, and Carole Handler, Exclusive Dealing, FullLine Forcing and Tying Arrangements, in 33rd Annual Advanced Antitrust Seminar: Distribution, Marketing, and Joint Ventures 235, 319 (PLI, 1993) ("What seems clear... is that Kodak will further complicate any attempt to expedite an antitrust lawsuit.").

${ }_{146}$ See Comment, Eastman Kodak Co. v. Image Technical Services, Inc.: The Decline and Fall of the Chicago Empire?, 68 Notre Dame L Rev 619, 662 (1993); Schwarzer and Hirsch, 45 Hastings $\mathrm{L}$ J at 15 (cited in note 10). See also note 10 concerning the resources that some antitrust cases have already consumed.

147 Jacobs, 79 Minn L Rev at 32 n 135 (cited in note 10).

148 Contract law should channel parties' intentions and disputes into expressions that courts are better at handling. See Fuller, 41 Colum L Rev at 801-02 (cited in note 136). 
sess incentives to make accurate disclosures, courts should have to make this inquiry infrequently. ${ }^{149}$

Nevertheless, to assess the proposed rule, decision makers should not simply consider how difficult it is for courts to decide if a price is fair. Rather, this difficulty should be compared directly to the difficulty of investigating the market imperfections cited in Kodak. ${ }^{150}$ In making this comparison, decision makers must weigh courts' experience in determining fair prices and appropriate disclosures in other contexts. ${ }^{151}$ Specifically, rule makers should consider courts' substantial experience in interpreting and enforcing contract terms in other contexts.

In sum, this rule creates incentives for OEMs to disclose information at the time of original equipment purchase, resulting in a smaller total number of disputes over aftermarket monopolies. ${ }^{152}$ Moreover, this rule creates incentives for OEMs as private actors to convey information ex ante, leaving courts to decide ex post whether this information was useful. Thus, the rule in question should conserve judicial resources, since through contract formation it will channel away many disputes and make summary judgment easier to obtain. ${ }^{153}$

B. The Proposed Rule Addresses the Two Main Information Problems in Aftermarket Monopolies

Under the proposed rule, as opposed to other proposed limits on Kodak, ${ }^{154}$ judges would consider the information problems

149 See Ayres and Gertner, 99 Yale L J at 124 (cited in note 105) (Legal formalities that force revelation of information to prospective disputants and possible future courts lower the costs of subsequent decision making.), citing Fuller, 41 Colum L Rev at 801-02 (cited in note 136).

150 See Allen-Myland, 33 F3d at 206 n 15.

151 See Priest, 90 Yale L J at 1297 (cited in note 12) (on the familiarity of warranty contracts). Compare Fuller, 41 Colum L Rev at 801-02 (cited in note 136) (on the usefulness of contract formalities for courts), with Hovenkamp, Federal Antitrust Policy $\$ 3.5$ at 105 (cited in note 1) (on the difficulty that judges have in dealing with issues such as the substitutability of different products and suppliers in antitrust law).

${ }_{152}$ See Ayres and Gertner, 99 Yale L J at 91 (cited in note 105) (Legal rules should be chosen in such a way as to give at least one party the incentive to create a contract; legal rules that encourage bargaining can "encourage the parties to reveal information to each other or to third parties (especially the courts).").

153 Id at 99 ("[S]ocial welfare may be enhanced by forcing parties to reveal information to a subsidized judicial system .....").

154 At least one writer has advocated overturning Kodak. See Arthur, 69 NYU L Rev at 76 (cited in note 103). See also Jacobs, $52 \mathrm{Md} \mathrm{L} \mathrm{Rev} \mathrm{at} \mathrm{368-73} \mathrm{(cited} \mathrm{in} \mathrm{note} \mathrm{5)} \mathrm{(advo-}$ cating three restrictions on Kodak: limiting it to its facts; developing a method to measure information gaps and then screening out cases where such gaps are small; and adding a tort-like causation requirement). 
that distort aftermarket prices. There are at least two such information problems. First, OEMs may strategically withhold information in order to create market imperfections that they can exploit. ${ }^{155}$ The OEM possesses more information, and depending on the details of the market in which it competes, it may be costly or even impossible for a consumer to otherwise acquire good information. ${ }^{156}$ Additionally, even without any bad intent by OEMs, consumers may be unable to afford the time and effort required to cope with the information they receive. ${ }^{157}$

The first problem, strategic withholding of information, has attracted the attention of legal scholars. ${ }^{158}$ Professors Ian Ayres and Robert Gertner have proposed that some contractual incompleteness may stem from one party strategically withholding information, decreasing the total gains from contracting in order to increase his or her share of those gains. ${ }^{159}$ The rule advocated here would induce OEMs to provide information, avoiding "incomplete" information about the future cost of aftermarket goods. The rule would reduce courts' administrative costs just as better written, more complete contracts do, as well as reducing businesses' legal costs and consumers' information costs.

Additionally, commentators have confronted the second problem, consumers' inability to process the information they receive. ${ }^{160}$ Consumers need information in forms that they can

ws See Jacobs, $52 \mathrm{Md} \mathrm{L} \mathrm{Rev} \mathrm{at} \mathrm{371-73} \mathrm{(cited} \mathrm{in} \mathrm{note} \mathrm{5)} \mathrm{(distinguishing} \mathrm{OEMs} \mathrm{that}$ neither generated nor abused market imperfections from those that did).

${ }^{156}$ See Kodak, $112 \mathrm{~S} \mathrm{Ct}$ at 2086. See also Stephen Salop, The Noisy Monopolist: Imperfect Information, Price Dispersion and Price Discrimination, 44 Rev Econ Stud 393, 393 (1977) (arguing that sellers exploit differences in levels of consumer information to maximize gain from poorly informed consumers).

${ }^{557}$ See, for example, Herbert A. Simon, From Substantive to Procedural Rationality, in 2 Models of Bounded Rationality 424, 430 (MIT, 1982) (noting that while economics traditionally has assumed actors to be infinitely capable of rational calculation in order to optimize their behavior, in the real world we must consider the limits on human mental abilities to gather and process information).

153 See, for example, Ayres and Gertner, 99 Yale L J at 99-100, 127 (cited in note 105); Jason Scott Johnston, Strategic Bargaining and the Economic Theory of Contract Default Rules, 100 Yale L J 615, 625-28 (1990); Ian Ayres and Robert Gertner, Strategic Contractual Inefficiency and the Optimal Choice of Legal Rules, 101 Yale L J 729, 735-44 (1992).

159 Ayres and Gertner, 99 Yale L J at 99-100, 127 (cited in note 105).

163 See, for example, Oskar Morgenstern, Thirteen Critical Points in Contemporary Economic Theory: An Interpretation, $10 \mathrm{~J}$ Econ Lit 1163, 1175 (1972) (Given the conditions of perfect competition, "[o]ptimal allocation is a conceptually simple matter for the consumer ... [however] [t] his may be computationally of phenomenal difficulty ...."). See also Howard Rachlin, John H. Kagel, and Raymond C. Battalio, Substitutability in Time Allocation, 87 Psychological Rev 355, $359 \mathrm{n} 1$ (1980) ("Economics is often said to be a science of rational behavior, but 'rationality' means no more to economists than conformity to economic theory. Economics is properly a science of maximization rather than 
handle. The rule in question would encourage OEMs to gather complex and wide-ranging information and to translate that information into the concrete terms and prices of supply contracts. Consumers can process information in the form of these contracts just as they can handle product warranties.

Disparities in information can cause problems in aftermarket product pricing not anticipated in classical economic theory. Adopting a legal rule that induces information sharing can correct market imperfections ex ante by educating "unsophisticated" consumers. Such a rule would set a clear legal standard for businesses to follow, promote summary judgment, and simplify adjudication of cases that go to trial.

\section{CONCLUSION}

As discussed above, there are several virtues in a rule that exempts from aftermarket liability those OEMs that convey information through contracts to provide aftermarket goods. This rule would provide OEMs guidance and conserve judicial resources while addressing the Court's recent concerns about imperfect information. But beyond these benefits, this rule continues a trend away from caveat emptor and toward requiring sellers to disclose information about various risks and costs that their customers may bear. ${ }^{161}$ Information is no longer "slum dwelling" in Stigler's "town of economics," in the law's central business district.

\footnotetext{
rationality.").

161 See Howard Beales, Richard Craswell, and Stephen C. Salop, The Efficient Regulation of Consumer Information, $24 \mathrm{~J} \mathrm{~L} \mathrm{\&} \mathrm{Econ} \mathrm{491,} 492$ (1981) (discussing the disclosures necessary for the exercise of "informed consent" to medical operations); id at 656-57 (discussing sellers' duties to warn buyers of potentially dangerous products); Fair Packaging and Labeling Act, 15 USC §§ 1451-61 (1988 \& Supp 1992) ("[I]nformed consumers are essential to the fair and efficient functioning of a free market economy.").

162 See George J. Stigler, The Economics of Information, $69 \mathrm{~J}$ Pol Econ 213, 213 (1961).
} 